\title{
English for Academic Purposes: Theory, Trends and Practices
}

- Gopal Prasad Pandey, PhD

Reader, Central Department of Education, TU

\begin{abstract}
English for academic purpose (EAP) emerged as a branch of English for specific purposes in the early 1980s. EAP grounds English language teaching in the linguistic demands of academic context, tailoring instruction to specific rather than general purposes. There is a growth of interest in EAP in the recent years. The interest in EAP developed in response to the growing need for intercultural awareness and of English as a lingua franca (ELF). EAP has become a major area of research in applied linguistics and focus of the courses studied worldwide by a large number of students preparing for study in colleges and universities. The increase in students' undertaking tertiary studies in English-speaking countries has led to a steady demand for the courses tailored to meet the immediate, specific vocational and professional needs. Thus, most universities in the present day world prioritize the role of academic skills. The aim of the paper is to examine the key approaches to the teaching of English for academic purposes, current trends in teaching EAP, and to argue the centrality and significance of EAP in the academia. The paper concludes by arguing that a greater emphasis needs to be placed on methodology in EAP.
\end{abstract}

Keywords/terms: English for academic purpose; English for specific purpose; general English; applied linguistics

\section{Introduction}

Over the past three decades, academic programmes designed to prepare nonnative users of English has grown into a multi-million-dollar enterprise around the world. Teaching those who use English for their study purposes differs from teaching English to those who learn English for general purposes and occupational purposes. For Dudley-Evans and St John (1998, p. 34), English for academic purposes (EAP) refers to "any teaching that relates to a study purpose." In a similar vein, Flowerdew and Peacock (2001, p. 8) define EAP as "teaching of English with the specific aim of helping 


\section{English for Academic Purposes: Theory, Trends and Practices}

learners to study, conduct research or teach in that language." EAP encompasses different domains and practices including not only study-skills teaching but also a great deal of what might be seen as general English as well. In fact, "EAP has emerged out of the broader field of ESP, a theoretically and pedagogically eclectic parent, but one committed to tailoring instruction to specific rather than general purposes". (Hyland and Hamp-Lyons, 2002, p. 2)

The main goal of EAP is for students to communicate effectively in academic environments. One key factor in reaching this goal is to know what the communicative requirements in these environments are. EAP stands for language research and instruction that lays emphasis on the specific communicative needs and practices of particular groups in academic contexts. This encourages practitioners to equipping students with the communicative skills to participate in particular academic and cultural contexts.

EAP has come out from the larger field of English for Specific Purposes as the academic 'home' of scholars who do not research in or teach other 'specific purposes', but whose focus is wholly on academic contexts (Hyland and Hamp-Lyons, 2002). The modern-day field of EAP addresses the teaching of English in the academy at all age and proficiency levels, and it draws on a range of interdisciplinary influences for its research methods, theories and practices. It seeks to provide insights into the structures and meanings of academic texts.

EAP is considered to be one of two branches of English for Specific Purpose (ESP) and the other being English for Occupational Purposes (EOP). Each of these branches can be subdivided according to the disciplines or occupations with which it is concerned. Thus EAP may be separated into English for Mathematics, English for Business, English for Pilots, English for Economics, English for Bank Managers etc. EAP approach differs from general English. It begins with the learner and the situation, whereas general English starts with the language. Many EAP courses/programmmes give more emphasis on reading and writing, while most general English courses place more focus on speaking and listening. General English courses tend to teach learners conversational and social genres of the language, while EAP courses tend to teach formal, academic genres.

The distinction between the two major branches of ESP is not clear cut. English for Business, designed to assist learners in their studies will clearly 


\section{English for Academic Purposes: Theory, Trends and Practices}

be EAP. At the same time, some university business courses like vocationally oriented courses, usually seek to prepare their students for business careers. English support for more vocationally- oriented aspects of the Business could perhaps be described as EOP as much as EAP. An English course designed to help students read economics textbooks would clearly be EAP, but a course designed to teach learners how to participate in business meetings or take phone calls has definitely an EOP dimension to it (Flowerdew and Peacock, 2001).

\section{Theoretical underpinnings}

Some important theoretical underpinnings relevant in the discussions made on EAP discourses are briefly discussed under the themes given below.

\section{Needs analysis}

The centrality of need analysis in teaching and evaluation EAP has been acknowledged by several scholars and authors (Richterich and Chancerel, 1977; Munby, 1978; Hutchinson and Waters, 1987; Brindley, 1989; Johns, 1990; West, 1994, 1997; Seedhouse, 1995; Jordan, 1997; Dudley-Evans and St. John, 1998; Richards, 2001; Finney, 2002; Grier, 2005; Long, 2005). Need analysis as the technique for "collecting and assessing information relevant to course design" (Hyland, 2006, p. 73), need analysis regulates course design and teaching (Hyland, 2006). This is because need analysis integrates the goal of individuals with the rules and requirements of the institution, with the pedagogical implications. Hence, need analysis "naturalizes what is socially constructed, making externally imposed rules seem not just normal but also immutable" by merging tactically learner needs with the institutional requirements (Benesch, 2001, p. 61). This implies that it could be viewed as "learning goals bringing to bear the teacher's values, beliefs and philosophies of teaching and learning" coconstructed by the teacher and his/her ELLs (Hyland, 2006, p. 74).

Need analysis is a procedure to collect information about learners' needs (Richards, 2001). The importance of NA is emphasized in English for Specific Purpose (Hutchinson and Waters, 1987) and English for Academic Purposes (Jordan, 1997), and also in general language courses espousing learner-centered curricula (Nunan, 1988; Tudor, 1996), task-based curricula (Long and Crookes, 1992), as well as performance-assessment. Clearly, the role of need analysis in any language course is indisputable. For Johns (1990), need analysis is the first step in course design and it provides validity and relevancy for all subsequent course design activities. 


\section{English for Academic Purposes: Theory, Trends and Practices}

Need analysis generally refers to the activities that are involved in collecting information that will serve as the basis for developing a curriculum that will meet the needs of a particular group of students. Pratt (1980, p. 79) states "needs assessment refers to an array of procedures for identifying and validating needs, and establishing priorities among them." The key phrases that make this definition different from the others are 'array of procedures' and 'validating needs'. The first phrase indicates that a variety of information gathering tools should be used. The second implies that needs are not absolute, that is, once they are identified, they continually need to be examined for validity to ensure that they remain real needs for the students involved. "The principal proponents of the use of need analysis were Richterich and Chanceral" (Nunan, 1988, p. 43). Need analysis, according to Richards (2001, p. 6), is "the requirement for fact finding or the collection of data from various sources, for example, the data about learners, the materials and so on." Need analysis procedures aim at determining what a particular group of learners expect to use English for and what their present level of competence is. Richards (2001, p. 5) suggests that need analysis serves three main purposes: it provides a means of obtaining wider input into the content, design and implementation of a language programme; it can be used in developing goals, objectives and content; and it can provide data for reviewing and evaluating an existing programme (as cited in Nunan, 1988, p. 43). In the field of applied linguistics, need analysis refers to "a number of means for identifying and validating the needs and establishes priorities among those needs" (Richards, 1990, pp.1-2).

\section{English for specific purposes}

English for specific purposes is an area of English language teaching which focuses on preparing learners 'for chosen communicative environments'. It differs from general English as it is based on a close analysis of the learner's communicative needs for a specific occupation or activity, as well as a detailed analysis of the language of that occupation or activity. As for a broader definition of ESP, Hutchinson and Waters theorize, "ESP is an approach to language teaching in which all decisions as to content and method are based on the learner's reason for learning" (Hutchinson and Waters, 1987, p. 19). ESP takes into account certain basic questions like: Who the learners are, what their linguistic background or level of competence is, what their necessities, wants and lacks are, what particular skills or subskills they need to develop, etc. 


\section{English for Academic Purposes: Theory, Trends and Practices}

\section{Sociocultural theory of learning}

The sociocultural constructivist theory of learning contributes to the theoretical construct of EAP due to its recognition of the socially constructed knowledge and responsiveness to the "complexities of institutions, teaching, and learning in local contexts" (Benesch, 2001, p. 4). EAP has evolved from its modest roots in the 1960 s to become an "emerging global phenomenon" by capitalizing on global challenges (de Chazal, 2014, p. 3). Grounded on the sociocultural constructivist theory of learning, University EAP opens more opportunities for integrating social activities and cultural practices as the source of critical thinking, the centrality of critical language pedagogy and praxis in students' holistic development, and the "inseparability of the individual from the social" (Moll, 1990, p. 15).

\section{Current trends in teaching English for Academic Purposes}

Modern day EAP teaching encompasses three major approaches which focus on study skills, general purpose EAP and specific purpose EAP respectively. The study skills give emphasis on developing students' control of a range of skills so that they can successfully participate in their study. These skills are regarded as common to all students within the university context, and so are independent of discipline and content. Students who are learning English for their study purposes need to know a wide range of skills namely; identifying main ideas in a text, distinguishing fact from opinion, guessing the meaning of words from context, note taking, summarizing, referring to source appropriately, recognizing the function of discourse markers, etc. In addition, EAP these days aims at developing an understanding of the discourse of academia and of the specific disciplines in students in which they are enrolled. They need to understand for example, types of questions that can be asked, the ways in which information is collected and analyzed, the purpose and form of common genres, the ways in which writes create a voice for themselves, and the use of appropriate forms of language.

\section{Practices}

English for academic purposes is a practical affair which focuses on investigating needs, preparing teaching materials, and devising appropriate teaching methodologies. It therefore provides informed and focused instructions based on need analysis.

Why EAP methodology. The main goal of EAP is to enable the students to communicate effectively in academic environments. One key factor in 


\section{English for Academic Purposes: Theory, Trends and Practices}

reaching this goal is to know what the communicative requirements in these environments are. Defining what EAP is explicitly will be of no use, if we cannot help students attain them, the goal of EAP will not be reached. In other words, in teaching EAP we need to consider the process of reaching the goal at least as much as the content that needs to be covered. Cheung and Wong (1988, p. 93) have mentioned EAP courses have three principal objectives which are as follows: (a) To communicate technical and business information effectively in the work and academic setting in several modes: written, oral, audiovisual and graphic., (b) To adapt material prepared in one form for presentation in another, for example to adapt a written business proposal for a boardroom presentation, and (c) To communicate effectively with specialist and non-specialist audience in job related task, for example writing memos and letters, chairing meeting, and interviewing or being interviewed.

Secondly the methodologies we use teaching EAP has been innovative and has created directions for general purpose English teaching to follow (Flowerdew and Peacock, 2001). For example, the idea that students' learning needs (or how they should learn) should be elicited to inform course design as well as their language needs stems from work in EAP (Hutchinson and Waters, 1987). Key factors behind the innovativeness of EAP teaching are that EAP teachers, especially in core countries are generally more experienced and qualified than general English teachers and that in the university environments where many EAP teachers work, research and innovation are valued. Such factors have pushed EAP to the forefront of the English teaching field.

Thirdly, there is a thin margin between the methods we use to teach EAP courses and general purpose English courses. The methods and methodologies we for teaching both the course are similar in many ways. The use of EAP innovations in general English teaching suggests that the methodologies of the two are closely related, but the existence of some approaches, such as team teaching, collaboration and cooperation which are unique to EAP implies a potentially distinct methodology.

\section{Methods in EAP}

The prime concern of the language teaching profession in the twenty first century was to find out the more effective method of language teaching. There are a number of reasons for the decline of the methods syndrome in contemporary discussions of language teaching. For Brown (2011), the term 
'method' is replaced by the term 'pedagogy'. The 'method' implies a static set of procedures while pedagogy suggests the dynamic interplay between teachers, learners, and instructional materials during the process of teaching and learning. Despite the fact that historically EAP came out at about the same time as the search for the 'best' method of teaching English was at its height, it seems that the macro-level of method has had very little influence on the teaching of EAP. This may be due in part to the restrictive nature of most methods, which prescribe how teachers should teach, whereas most EAP teachers are professionals who feel confident about their own ability to make decisions concerning teaching.

\section{Approaches in EAP}

A substantial amount of work related to approaches in teaching EAP has been investigated. There are lists of principles that guide EAP teaching. For example, in discussing the whole of ESP, Hutchinson and Waters (1987) list eight principles including: language learning is an active process, language learning is an emotional experience, and language learning is not systematic. There are also global teaching and learning practices from which principles can be drawn.

The first set of common practices that seems widespread in teaching EAP involves inductive learning. Practitioners prefer inductive learning to more teacher-centred deductive approaches. The widespread use of concordancing in EAP (Jordan, 1997; Stevens, 1991), the teaching of reading focusing on text analysis (Holme, 1996; Paltridge, 2002), and approaches where students are encouraged to act as researchers investigating academic communities (Johns, 1997) all place a particular emphasis on induction.

The teaching EAP also makes use of process syllabuses (Widdowson, 1990) involving task-based and project-based learning. Both the approaches are quite common in English for general purposes, much of the initial impetus for task-based and project-based learning came from EAP teaching (Halland Kenny, 1988) where they are still frequently used. Other approaches like self-access learning (Jordan, 1997; Lynch, 2001), the use of negotiated syllabuses (Martyn, 2000), and the self and peer assessment and feedback are also in practice in teaching EAP. All of these aim to promote learner autonomy.

Technology is all around us. It does not matter where you are, technology is every where: at home, in the street, at work, at school, in your bag and sometimes or quite often even in your hands. Our children in the digital era 


\section{English for Academic Purposes: Theory, Trends and Practices}

and live their digital life as digital natives. So technology can be used as a tutor, tutee and tool (Walker and White, 2013).

Team teaching or cooperating with content teachers is an approach closely linked to the nature of EAP teaching (Dudley-Evans and St. John, 1998). Although most work in EAP has focused on the tertiary level, team teaching is an approach which has also received attention in secondary and even primary level EAP. The six approaches on which teaching EAP generally places a greater emphasis than other types of English teaching therefore are:

1. focus on inductive learning;

2. using process syllabuses;

3. promoting learner autonomy;

4. using authentic materials and tasks;

5. integrating technology in teaching;

6. using team teaching.

It should be noted that these six approaches are not mutually exclusive. The six approaches which are based on reported practice given here are very different from the principles guiding EAP teaching given in Hutchinson and Waters (1987). To some extent, the differences may be due to the different purposes of the lists, but it may also be due to the differing sources of the lists: the list of principles is based on theory, whereas the six approaches above are derived from reports of teaching and learning practice and are thus of more immediate use for teachers.

\section{Techniques in EAP}

Techniques are more specific than approaches and are often equated with activities (although techniques may also include such things as a specific way of giving an explanation which would not normally be categorised as an activity. As specific teaching/learning practices, techniques may be specific to a certain objective and thus lack generalisability. A few techniques such as brainstorming, however, can be applied to a wide range of objectives and situations. An example of a technique specific to EAP is asking students to create algorithms to show their understanding of the process of using contents and indexes to search for information in books.

\section{Salient Features of EAP Approach}

The most significant characteristic feature of EAP the needs of the students and thus the content and goals of teaching. The reason behind teaching for 
Specific Purposes, including EAP is that teaching is designed to meet the specific needs of the students (Strevens, 1988). In EAP, these needs, and thus the teaching, relate to a study purpose (Dudley-Evans and St. John, 1998), and EAP is largely founded on the fact that the English used to fulfil these study needs stand in contrast to general English (Strevens, 1988). In addition, EAP makes the use of specific genres.

A second characteristic of tertiary EAP that influences methodology is the nature of the students (Flowerdew and Peacock, 2001). Generally, EAP students are more mature, more self-directed and more aware than students of English for general purposes. These student characteristics are, in fact, the characteristics which are most likely to lead to successful learner autonomy. (Breen and Mann, 1997; Brundage, 1980), and it is therefore perhaps unsurprising that approaches emphasizing learner autonomy are relatively frequent in EAP. Thirdly, the practicalities of many EAP situations are frequently distinctive. For example, the informants expert in the content of teaching are frequently available and cooperative enabling the use of teamteaching in EAP. In other English language teaching situations, this is not usually the case. From a more practical perspective, EAP situations frequently have more resources than other English language teaching situations. These greater resources facilitate several types of project learning. The nature of EAP situations, then, often allows approaches to be used which other situations may wish to use but which are constrained by practical factors.

In discussing ESP and EAP, Strevens (1977) argued that courses can be specific in fours ways:

1. EAP is centered on the language (grammar, lexis, and register), skills, discourse and genres appropriate for learners. EAP restricts the language items to be taught, i.e, incorporates only those skills which are required for the learner's immediate purposes;

2. EAP selects from the whole language only those items of vocabulary, grammar patters, linguistic functions, etc. which are required for the learners' immediate purposes;

3. EAP includes only topics, themes and discourse contexts that are directly relevant to the learner's immediate language needs; and

4. EAP addresses only those communicative needs that relate to the learner's immediate purpose. 


\section{English for Academic Purposes: Theory, Trends and Practices}

It can be seen that when all four kinds of specificity are applied to a course, the result is something quite restricted; this restriction resulted in some dissatisfaction with early approaches to ESP. EAP, on the other hand, has generally managed to escape these problems because the academic context has approved able to provide subject matter that is sufficiently specific and relevant to satisfy learners needs. It is also offers subject matter that can satisfy some of the broader educational and social aims that learners and teachers bring to the education process.

\section{Design and Methodology in EAP}

There are several ways in which methodology can be incorporated into programme design. First, methodology can be given precedence over content. This is frequently the case in process syllabuses such as the course length project of Hall and Kenny (1988), and can also be seen in some more traditional syllabuses. For example, controlled practices, communicative relevance, linguistic rationales and problem solving can be priorities in designing an EAP speaking course (James, 1983). Second, methodology can be dictated by content. For example, in an interesting comparison of published advice on thesis writing and actual practice, having identified certain course objectives, Paltridge (2002) then turns to the classroom implications of these objectives.

\section{Conclusion}

EAP is a branch of ESP, tailored to the needs of the learners at various levels. It is one of the key courses taught in many English-medium universities to facilitate the acquisition of academic literacy skills. The teaching of EAP begins with the analysis of the students' linguistic background, what they have known and what they need to know. So, need analysis is the departure point of EAP courses.EAP now become a fully developed branch of applied linguistics which entails a significant body of researches into effective teaching and assessment approaches.EAP is a thriving and significant aspect of TESOL that has so far received less attention from researcher than it deserves. The goal of EAP is to empower the students with an analytical framework which assists them to reflect on both their own language practices and practices they encounter in their disciplinary studies. The emphasis on practical outcomes has become the concern of EAP today. Its greatest strength is its responsiveness to the needs of the learners. Current EAP teaching is characterized by three major approaches, which focus on study skills, general purpose EAP, and specific 


\section{English for Academic Purposes: Theory, Trends and Practices}

purpose EAP respectively. The study skills approach aims to develop students' control of a range of skills deemed to necessary for successful participation in tertiary study. These skills are regarded as common to all students within the university context, and so are independent of discipline and content. EAP now has become a purely pragmatic enterprise, methodologically-driven set of practices concerned exclusively with practical outcomes.

\section{References}

Benesch, Sarah. (2001). Critical English for academic purposes. NJ: Lawrence Erlbaum Associates Inc.

Breen, Michael P.; and Mann, Sarah J. (1997). Shooting arrows at the sun: Perspectives on a pedagogy for autonomy. In Benson, Phil and Voller, Peter (Eds.), Autonomy and independence in language learning; pp. 132-149). London: Longman.

Brindley, Geoffery. (1989). The role of need analysis in adult ESL program design. In Johnson, Robert Keith (Ed.), The second language curriculum (pp. 63-78). Cambridge: Cambridge University Press.

Brown, H. Douglas. (2011). English language teaching in the 'post-method' era: Toward better diagnosis, treatment, and assessment. In Richards, Jack C. and Renandya, Willy A. (Eds.), Methodology in language teaching, pp. 9-18. Cambridge: Cambridge University Press.

Brundage, Donald. H. (1980). Adult learning principles and their application to program planning. Ontario: Ministry of Education.

Cheung, D.; and Irene, Wong. (1988). The communication skills and ESP interface: The course at the Nanyang Technological Institute, Singapore. In Tickoo, Makhan Lal, ESP: The State of the Art, pp. 9096. SEAMED RELC.

de Chazal, Edward. (2014). English for academic purposes. Oxford: Oxford University Press.

Dudley-Evans, Tony; and St. John, Maggie Jo. (1998). Developments in English for specific purposes. Cambridge: Cambridge University Press.

Finney, Denise. (2002). The ELT curriculum: A flexible model for a changing world. In Richards, Jack C.; and Renandya, Willy A. (Eds.), Methodology in language teaching: An anthology of current practice, pp. 69-79. Cambridge: Cambridge University Press. 


\section{English for Academic Purposes: Theory, Trends and Practices}

Flowerdew, John; and Peacock, Matthew. (2001). Issues in EAP: A preliminary perspective. In John, and Peacock, Matthew (Eds.), Research perspectives on English for academic purposes, pp. 8-24). Cambridge: Cambridge University Press.

Grier, Alan S. (2005). Integrating needs assessment into career and technical curriculum development. Journal of Industrial Teacher Education, 42 (1), pp. 59-66.

Hall, David; and Kenny, Brian. (1988). An approach to a truly communicative methodology: The AIT pre-sessionalcourse. English for Specific Purposes, 7, pp. 19-32.

Holme, Randle. (1996). ESP ideas. London: Longman.

Hutchinson, Tom; and Waters, Alan. (1987). English for specific purposes: A learning-centred approach. Cambridge: Cambridge University Press.

Hyland, Ken; and Hamp-Lyons, Liz. (2002). EAP: Issues and directions. Journal of English for Academic Purposes, 1, pp. 1-12.

Hyland, Ken. (2006). English for academic purposes: An advanced resource book. New York, NY: Routledge.

James, K. (1983). The teaching of spoken English to overseas students in a British university. In Jordan, Robert R. (Ed.), Case studies in ELT, pp. 56-66). London: Collins.

Johns, Ann M. (1997). Text, role and context: Developing academic literacies. Cambridge: Cambridge University Press.

Johns, Ann. M. (1990). ESP: Its history and contributions. In Celce-Murcia, Marianne (Ed.), Teaching English as a second or foreign language $\left(2^{\text {nd }}\right.$ ed.), pp. 67-78. New York: Newbury House.

Jordan, Robert R. (1997). English for academic purposes: A guide and resource book for teachers. Cambridge, CB2: Cambridge University Press.

Long, Michael H.; and Crookes, Graham. (1992). Three approaches to taskbased syllabus design. TESOL Quarterly, 26 (1), pp. 27-56.

Long, Michael H. (2005). Methodological issues in learner need analysis. In Long, Michael H. (Ed.), Second language needs analysis (pp. 19-76). Cambridge: Cambridge University Press. 
Lynch, Tony. (2001). Promoting EAP learner autonomy in a second language university context. In Flowerdew, John and Peacock, Matthew (Eds.), Research perspectives on English for academic purposes, pp. 390-403. Cambridge: Cambridge University Press.

Martyn, Elaine. (2000). Syllabus negotiation in a school of nursing. In Breen, M. P.; and Littlejohn, A. (Eds.), Classroom decision-making: Negotiation and process syllabuses in practice, pp. 150-162. Cambridge: Cambridge University Press.

Moll, Luis C. (1990). Vygotsky and education: Instructional implications and applications of sociohistorical psychology. Cambridge: Cambridge University Press.

Munby, John. (1978). Communicative syllabus design. Cambridge: Cambridge University Press.

Nunan, David. (1988). The learner-centred curriculum: A study in second language teaching. Cambridge, CB2: Cambridge University Press.

Paltridge, Brian. (2002). Thesis and dissertation writing: An examination of published advice and actual practice. English for Specific Purposes, 21, pp. 125-144.

Pratt, David. (1980). Curriculum design and development. New York: Harcourt Brace Jovanovich.

Richards, Jack C. (1990). The language teaching matrix. Cambridge: Cambridge University Press.

Richards, Jack C. (2001). Curriculum development in language teaching. Cambridge: Cambridge University Press.

Richterich, Rene; and Chancerel, Jean Louis. (1977). Identifying the needs of adults learning a foreign language. Strasbourg: Council of Europe/Oxford: Pergamon.

Seedhouse, Paul. (1995). Need analysis and the general English classroom. ELT Journal, 49 (1), pp. 59-65.

Stevens, Vance. (1991). Classroom concordancing: Vocabulary materials derived from relevant, authentic text. English for Specific Purposes, 10, pp. 35-46.

Strevens, P. (1977). Special purpose language learning: A perspective. Language Teaching and Linguistics Abstracts, 10, pp. 145-163. 


\section{English for Academic Purposes: Theory, Trends and Practices}

Strevens, P. (1988). ESP after twenty years: A re-appraisal. In Tickoo, M. (Ed.), ESP: State of the art, pp. 1-13. Singapore: SEAMEO Regional Language Centre.

Tudor, Ian. (1996). Learner-centeredness as language education. Cambridge: Cambridge University Press.

Walker, Alisha; and White, Goodith. (2013). Technology enhanced language learning. Oxford: Oxford University Press.

West, Richard. (1994). Need analysis in language teaching. Language Teaching, 27 (1), pp. 1-19. doi:10.1017/S0261444800007527.

West, Richard. (1997). Needs analysis: State of the Art. In Howard, R. and Brown, G. (Eds.), Teacher education for ESP, pp. 68-79. Clevedon, UK: Multilingual Matters.

Widdowson, H.G. (1990). Aspects of language teaching. Oxford: Oxford University Press. 